\title{
Reformed theology and the identity of the Christian congregation'
}

\author{
W. D. Jonker \\ Department of Systematic Theology \\ University of Stellenbosch \\ STELLENBOSCH
}

\section{Abstract \\ Reformed theology and the identity of the Christian congregation}

Throughout the ages, the role of theology was understood to be that of serving the church to become what it should be, to become true to its own identity. In the theology of the Reformation, the identity of the congregation was sought in its being created and sustained by the Word of God. Consequently, theology was intended to serve the preaching, teaching and pastoral care of the congregation. However, since the Enlightenment, theology as a university discipline has been deeply influenced by the presuppositions of the modern spirit and has mostly lost its close relationship with the church. Because of its resultant critical approach to the Bible it often destroyed the very fahric of the gospel by which the church should live. It often became an impediment on the way of the congregation to remain true to its spiritual identity. The author contends that the time has now come to see the presuppositions of the Enlightenment for what they are: relative and one-sided, the biased assumptions of a positivistic era which is rapidly drawing to its end. He is of the opinion that theology should not aspire to operate within the limits of the modern world view, but accept the challenge to operate on the basis of the faith of the congregation as interpretative community, and to read the Bible as the Book of the church with the presuppositions of the Christian faith.

Originally presented as a paper at the conference on "The Vitality of Reformed Theology", the Netherlands (June 1994). The paper has been published in Veeling, K. ed. 1994. The Vitality of Reformed Theology. Kampen : Kok. 


\section{The close relationship between theology and congregation}

Our discussion of the vitality of Reformed theology would be incomplete if we did not take time to consider the unique relation between Reformed theology and the Reformed congregation. A statement by W. van ' $t$ Spijker seems to be of great significance for our subject. In a free translation I would render it as follows:

Without dealing with the interesting and vital problem of the relation between church and theology, one may state without hesitation that this relation is of a vital character. It is in fact so vital, that in the long run the character of the church is conditioned by its theology (Van 't Spijker, 1974:40).

We could easily prove this by looking at the history of the church from this perspective. For our purpose, however, it is enough to recall the way in which the theology of the Reformed branch of the Reformation shaped the character of the Christian congregation.

\subsection{The role of theology}

Throughout the ages, theology understood its role to be that of serving the church to become what it should be: to be true to its own identity. During the greater part of the history of the Christian church, theology was regarded as the attempt to understand the meaning of God's revelation as it was given to Israel in the old covenant, as it found its fulfilment in Jesus Christ in the new covenant, as it is proclaimed in the Holy Scriptures, and as it is believed by the Christian church. Thus the purpose of theology was to study and interpret the Bible and the documents of the Christian faith in order to build up the congregation in its faith and to equip it to fulfil its calling in the world.

In the 11th century, Anselm of Canterbury expressed this characteristic of theology by defining it as fides quaerens intellectum: faith that seeks to understand (Barth, 1958:14ff). This means that the point of departure for theology is the reality of the faith of the church which is shared by the theologian. This faith is awakened by the Word of God and is a gift of God's grace. The congregation lives by the knowledge of God as he reveals himself in the Scriptures. The proper task of theology is not only to enrich the theologian by helping him or her to grasp more fully how 
wide and long and high and deep the love of Christ is, but more particularly it is also to assist the congregation to understand that love together with all the saints (Eph. 3:18).

Reformed theology may be described as that modality of Christian theology that is practised within the tradition of the Reformed branch of the Reformation. From the outset Reformed theology, which was shaped by the rediscovery of the gospel in the 16th century, had as its main objective the desire of building up the church of God in its knowledge and faith, its obedience and its hope, in order that the church might become what it should be. In essence, the theology of the Reformation was an affirmation of the primary authority of Scripture. It was a joyous discovery of the liberating power of the gospel of God's grace in Jesus Christ. The new wine of the message of salvation by grace alone burst the old wineskins of the scholastic theology of the Middle Ages (cf. Mt. 9:17). Theology became an exceedingly practical reflection on the Word of salvation by which the congregation lives. In the theology of Luther, Calvin and the other main figures of the Reformation, we encounter a continuous preoccupation with Scripture itself. These Reformers probed into Scripture's joyful message and tried to capture the meaning of the law and the gospel for the life of the Christian congregation (De Moor, 1980:47). Their theology was forged in the struggle to reform the church. This process is especially visible in the history of different local congregations like Zürich, Berne, Basle, St. Gallen, Strassbourg, Geneva and elsewhere. Zwingli, Oecolampadius, Farel, Bucer, Bullinger and Calvin all contributed to the restructuring of local congregations to enable them to become churches of the Word. In this process of restructuring, Reformed theology was born and nourished.

The work of Calvin in Geneva is a unique demonstration of how closely the organisation of the congregation and its own theological program were linked together (Bouwsma, 1988). Calvin's theology developed in the course of his pastoral duties. He had to preach, to instruct, to provide catechism for the children, to formulate a church order, and to write commentaries on the books of the Bible for the edification of preachers and members of the congregation alike. He was not inspired by academic interest alone, but by the spiritual needs of the congregation. Of course Calvin's main aim, like Luther's, was to understand more fully the gospel 
of grace. Like Luther, the soteriological question dominated his quest for the truth. From the outset, however, Calvin's theology, and that of the whole Reformed branch of the Reformation, developed a broader scope than Luther's: it included the life of the church and its calling in the world. Within the sphere of influence of Calvin and his close associates a specific Reformed view of the identity of the Christian congregation was born. This identity had to be served and protected.

\subsection{The identity of the congregation}

We deliberately use the term identity here in order to emphasise the essential character of the Christian congregation. Lately, identity has frequently been used to describe the characteristics of the congregation. Hough and Cobb (1985:24) defined the identity of the congregation in general terms as the institution that in various ways keeps alive the memory of Israel's life with God as perceived in and through Jesus and the apostolic witness to him. Alternatively, the identity of the church is constituted by its responsibility to make effective the memory and the resulting anticipation of God's creative and redemptive activity in the world (Hough \& Cobb, 1985:27). While such general descriptions of the identity of the congregation are plausible within a specific context, they are not specific enough for our purpose.

Jackson W. Carroll (1991) states that congregations, like individuals, have identities. Each existing congregation has its own identity. He defines this identity as "the persistent set of beliefs, values, patterns, symbols, stories, and style that makes a congregation distinctive" (Carroll, 1991:125). Hopewell (1987) expresses himself in the same vein. In this sense one can also say that denominations have certain identities which can be described empirically (cf. the series: Die Kirchen der Welt, published by the Evangelisches Verlagswerk since 1964). Recently, in a double edition of The Reformed World (Vol. 431 \& 2, 1993), published by the WARC, the specific characteristics of a number of Reformed churches in different parts of the world have been described in this way. While such descriptions inform us about the actual state of affairs in different churches or denominations, they tend to be more phenomenological than theological. What really interests us here is the theological identity of the church, an identity to which it should remain 
faithful in its faith and life. Carroll (1991:125) touches on this when he states:

Even as each congregation has a distinctive identity, each is also a particular embodiment of the body of Christ. Thus, insofar as a congregation is faithful in its calling to be the church, its particular identity is also an expression of Christian identity.

When we speak about the theological identity of the congregation we mean nothing else than its 'being the Christian church', representing the body of Christ. This identity is given in Christ. Yet, this identity also contains an imperative to the church. Like the individual believer, the church should also constantly strive to be and to become what it already is in Christ. It should become true to its own spiritual identity.

How should theology in general, but more specifically Reformed theology, aid the church in this regard? The first way in which it should do this, is to serve the church with theological clarity concerning its own identity. As far as this is concerned, Reformed theology has made an enormous contribution. The Reformed theologians - Bucer, and deeply influenced by him, John Calvin - provided the Protestant movement with an exegetically based doctrine of the church that clarified its identity and led to the creation of organisational structures which were designed to protect and guide the church towards becoming increasingly true to its spiritual reality. This identity of the church is outlined in the historical Reformed confessions, such as the Confessio Gallicana, the Confessio Belgica, the Scottish Confession, the Confession of Westminster and others (cf. Gassmann, 1968; Jacobs, 1959:102-104). Two decisive aspects are evident in the Reformed confession about the church:

* The church is defined in soteriological rather than in institutional terms. Following the terminology of the Apostolic Confession, the church is spiritually defined as the one, holy and catholic church, the communion of the saints. The church is identified with the body of Christ, that is, with all people who are elected and saved in Christ, from the beginning of the world until its end (cf. Heidelberg Catechism 54 and Belgic Confession 27).

* The church is defined as the fruit of the saving work of Christ himself through his Word and Spirit, as a creatura Verbi. Thus the marks of 
the true church are the purity of the gospel preached, the pure administration of the sacraments and the exercise of church disciphine (Confessio Belgica:27).

The combination of these two aspects also brings with it the characteristic Reformed dialectical relation between the church universal and the local congregation. The church is that spiritual reality which is essentially universal, but is also simultaneously visible and tangible in the local congregation, which is the church of God at a specific time and place. The term congregation therefore can be used interchangeably for the local church as well as for the church universal (Confessio Belgica:27; Heidelberg Catechism:54). The universal church consists of the local congregations gathered around Word and sacrament. The local congregation is a church of Christ in its own right. As such, it is a complete manifestation of the universal congregation of Christ at a specific place, and not just a parish or part of a larger diocese within the church at large. Balke says that, while Calvin firmly believed in the unity of the universal church of Christ which in its essence is invisible, at the same time he also stressed that the church of Christ is visible in the local congregations (Balke, 1992:122-123). Together these congregations form the visible universal Church which is the Mother of the believers. For this reason it is necessary that the local congregations should foster their communion with one another (Balke, 1992:123).

\subsection{The Reformed accent on the Word}

We should not overlook the tremendous importance of this stance for the character and identity of the church. By identifying the church in the local congregation, the danger of large scale institutionalism was avoided. The locus of the church was primarily seen as the concrete gathering of the flock of God around the Word and the sacraments. This brings us to the second way in which theology should serve the congregation: it should foster the understanding, interpretation and application of the Scripture in such a way that the church may be built up and equipped for its service in the world.

The church is born from, and constituted by the Word of God as it is preached and confirmed in the sacraments. This view inspired the way in which the Reformed branch of the Reformation organised the church. 
Calvin energetically organised the congregation in Geneva and inspired the whole Reformed movement to do the same (Niesel, 1960:207f). One could describe the identity of the church in the Reformed sense by stating that it is the flock of Christ, gathered and protected by Him to live by faith in the promises of God. But it is also necessary to remember that the real identity of the congregation should not be sought in its own subjective religiosity, but in its being created and sustained by the Word of God. The Word, and not the subjective experience of the congregation, forms the heart of the Reformed idea of the identity of the church, and thus also of the Reformed spirituality. The Reformed congregation is intended to be a well-organised community of mature Christians. Gathered around the Word and the sacraments and leading an orderly and disciplined life as the flock of Christ, Christians are called to live in the fullness of the salvation offered by Christ, and to discern for themselves the signs of the times and the kind of witness which the Word of God demands of them.

For this reason from the beginning there has been a strong accent on the preaching of the Word. Leith (1988:25) writes:

Protestantism, and the Reformed type of Protestantism in particular, depended primarily upon preaching to accomplish what the sacramental system of medieval Catholicism was failing to do in the sixteenth century: namely, to communicate God's grace to human beings.

He stresses that the Reformation can best be understood as a revival of preaching. He refers to the Tetrapolitan Confession of 1530 which started with a chapter called: "Of the Subject-Matter of Sermons", as well as to the decisive statement of the Second Helvetic Confession (1566): Praedicatio Verbi divini est Verbum Dei (Leith, 1988:24-25. Cf. also Bakker, 1957:6f). Calvin insisted that it was the will of God that the church should be built up by preaching (Institutes, IV,1:5-6). The pulpit with the Bible open on it became the central position in the Reformed church building and church service. The preaching and hearing of the Word formed the heart of the church service. The participation of the congregation consisted mainly in its hearing of the Word of God. The significance of hearing as congregational participation in the service should not be minimised. Calvinists believe that hearing the Word of God is the crucial act in worship. The proper response to that hearing is 
prayer, singing, the affirmation of the faith and the receiving of the sacraments (Leith, 1988:27).

The strong accent on preaching had a decisive influence on the character of Reformed theology. It stimulated its practical character so that theology was not practised for its own sake, but was practised in order to build up the congregation. Although with Anselm, Reformed theology could understand itself as fides quaerens intellectum, its interest was not as speculative as Anselm's. Reformed theology wanted to understand the message of the Bible in its relevance for the life of the congregation. It was geared to serve the preaching, teaching and pastoral care of the church. This meant that the type of exegesis that was practised was far more than a literary or philological explanation of the text. It was an exposition of the text within the canon as a whole, and it was read against the backdrop of the confessional and salvation-historical interpretation of the Biblical message.

\subsection{The character of Reformed spirituality}

The accent on preaching also had a decisive impact on the identity of the Reformed congregation and the kind of spirituality that was fostered in it. Much has been written about that lately (Velema, 1990; Graafland, 1990; Van 't Spijker et al., 1993; Jonker, 1989). Reformed spirituality contains a marked combination of mystical depth and moral activity. This makes it difficult to contain all its aspects in a simple description. This difficulty is not strange when considered in the light of the Reformed respect for the sovereignty and holiness of God. Such respect brings with it not only a deep sense of awe, but also a profound commitment to obey God's will. This sense of respect and awe is in keeping with the love of Reformed Christians for the whole Bible as Old and New Testaments. The result is that Christians' spirituality is not only inspired by the gospel message of the New Testament, but also by the message of the Law and the prophets of the Old Testament.

In no other tradition within Christianity do the Old Testament play such an enormous theological role as in the Reformed churches. The Psalms and the Prophets especially feature in a way that has a marked influence on Reformed spirituality. The theology of Van Ruler, amongst others, has opened our eyes to the importance of the Old Testament in the Reformed 
understanding of the Christian faith (cf. Van Ruler, 1955). Of great importance also is the way in which the three-fold office of Christ features in Reformed theology as the complete fulfilment of the old covenant. Reformed theology inspired a deep sense of reverence for the priestly office of Christ as celebrated at the Lord's Table; as well as a great respect for his office as Prophet as encountered in the preaching of the Word; and a clear vision of his office as King, as expressed in the wellknown assertion of Kuyper that there may be no inch of this world that should not be brought under the dominion of Christ (Kuyper, 1930:32). Whereas Lutherans gloried in the message of justification by faith and tended to use one word to describe the redemption, Calvinists used two. They rejoiced with the Lutherans in the grace of justification, but were simultaneously fascinated by the Biblical call to sanctification.

Calvinists lived by the gospel of the sovereign grace of God in such a way that it could inspire the service and praise of God in all spheres of life. In accordance with the Lutherans Reformed Christians understood the Law as the mirror of sin, but in accordance with Calvin they regarded the Law in its moral sense as still valid for Christians - the so-called third use of the Law (Wendel, 1976:196-208). Their love for the Law was imbedded in their general appraisal of the Old Testament and especially in their love for the concept of the covenant. Whereas Luther rejoiced in the promissio of God, Reformed Christians rejoiced in the covenant of God with his people (Klappert, 1976). Reformed Christians praised God for the salvation of the individual, but at the same time they treasured the idea of the covenant constituted by believers and their households. They even dreamt about the reality of a Christian nation and a Christian commonwealth. They were taught not only to live for themselves and for their families, but also for the society to which they belonged. They felt that they had an obligation to Christianise the world, not only by bringing men and women to an acceptance of Christ, but also by ordering life in its totality according to the law of God. Politics, economics, science and jurisprudence - every sphere of life was to be brought under the sovereignty of God. This belief accounts for the fact that Reformed Christians were nearly always politically alert. Some of the valid elements of truth stressed by contemporary political theology were in reality already 
included, although within a quite different setting, in the Reformed concept of the kingship of Christ over all spheres of life (Jonker, 1987:86).

It is not strange that this type of spirituality led the Reformed branch of the Reformation to foster the idea of a congregation of well-informed Christians, Christians come of age, able to distinguish for themselves between right and wrong, truth and error. In her portrayal of crosssections in the Christian community in the Netherlands, Liebje KuylmanHoekendijk described Reformed Christians as having a deep commitment to, and a love for the truth as formulated in their confessions of faith. The whole life of the congregation revolves around the truth of the doctrine, and much stress is placed on the covenant and a joyous reading of the Old Testament (Kuylman-Hoekendijk, 1969:50ff). This could be the case only, because Reformed Christians have often had a keen interest in theology. More than any other confessional grouping, the Reformed churches in their best periods cherished the services of theology. There were times in the history of the Netherlands, for instance, when ordinary members of the congregation were very well informed about theological matters. They felt that they could and should understand what theology was all about, so that they themselves could judge the Biblical character of the views expressed and advocated by theologians. Theological literature formed part of the home library, and serious theological problems could form the topic of discussion when friends visited. They obviously did not regard theology as an academic and esoteric science of interest to theologians only, but as a form of self-reflection by the Church on the revelation of God by which it lives.

\section{The impact of the Enlightenment}

The picture that I have been painting is idealistic of course. It represents a dream that is not easily realised. Even during its best periods, the church has always been accompanied by weakness and failure. Moreover, the extent to which this dream could be realised is dependent on specific factors. The main factor in this regard is the unqualified acceptance of the Scriptures as the Word of God and the willingness to obey that Word as the only norm for the life of the church. In the dynamic situation of the proclamation of that Word in the power of the Spirit, the congregation is built up in faith and obedience to be a living church of God. 


\subsection{The rise of Rationalism and Pietism}

Unfortunately, very soon the spirit of the Reformation was threatened by the emerging Orthodoxy. The rationalism of the scholastic methods used by the Protestant Orthodoxy threatened the relation between theology and pulpit. Rossouw told the fascinating story of how the lively and existential reading of the Bible by the Reformers in its clarity as Word of life, was lost as the emerging Protestant Orthodoxy started treating the Bible as source of proof-texts for the doctrinal system of the church (Rossouw, 1963:271-297). Theology, which should be nothing else than the endeavour to read, understand and interpret the Bible as the Word of God in order to serve the preaching, teaching and pastoral care of the congregation, developed instead into an uninspiring rational system of thought. When the Enlightenment hit the Church in the 18th century, the evangelical and theological momentum of the Reformation had been lost already.

The reaction of the Pietists and Methodists was understandable. In many respects they kept alive something of the true intentions of the Reformation. The problem was, however, that they shifted the focus of attention: religious experience, rather than the Word of God and the gospel of grace, became central. Despite their enormous impact, especially in the English speaking world, and their formidable missionary action which led to the expansion of Christianity in many parts of the world, they could not revitalise the spirit of the Reformation. The life of faith often withdrew itself into the inner sphere of personal religiosity and concentrated on personal feeling and subjective experience.

\subsection{The cultural shift of the Enlightenment}

Nobody should underestimate the pressures the modern period exerted upon the church. The Enlightenment brought with it a radical change in the mindset of Western man (Heron, 1980:1-21; Berkhof, 1985:11-19). It represented a cultural shift based on new presuppositions that would henceforth dominate the modern mind and confront theology with its greatest challenge since the time of the apostles. The Church was faced with the rising tide of secularism.

To meet this challenge, a totally new approach to the Bible as the Word of 
God was introduced. This had an enormous impact on the relation between theology and the congregation (Van Genderen \& Velema, 1992:81-82). The historical-critical method meant that positivistic presuppositions were applied in Biblical research, excluding faith in the truth of the Bible as a valid point of departure (Runia, 1972:12). Presuppositions play a decisive role in the process of understanding (Grant \& Tracy, 1984:134f, 181f). The modern concept of science as an objective and unbiased search for the truth as rational knowledge simply ruled out the idea of theology as fides quaerens intellectum. Consequently, theology could only retain its status as a university discipline by adapting itself to the new rules of the game. It had to accept the ideal of being a purely objective and rational science that could no longer find its basis in the faith of the congregation and the truth of the revelation. To be acceptable, theology had to become a critical study of the documents and history of the Christian faith as part of the study of the phenomenon of religion (cf. Scholder, 1966; Pannenberg, 1973:255ff; Lindbeck, 1984:124). Theological faculties partly became faculties of literary and historical studies, and partly faculties of religion. Even when the term theology was retained, its character was nevertheless radically altered.

Within the confines of a positivistic world view, it became impossible for the theologian to read the Bible with the same eyes as Augustine, Luther or Calvin - or for that matter, as all the saints. Traditional theology read the Bible with the presupposition that it was the Word of the living God through which he still speaks in the power of the Holy Spirit. Modernism, however, lost the concept of Scripture as the Word of God (Marxsen, 1968:107f). The Enlightenment brought with it a new "fiduciary framework", as Lesslie Newbigin calls it, using a concept coined by Polanyi. The principles of the Enlightenment regulated the total intellectual world, including Biblical scholarship. Says Newbigin (1985:43):

Basic to this approach ... was the shift from an 'explanation' (of the Bible) which took revelation as the starting point to an 'explanation' based on the observation and analysis of observable facts with a view to discovering their 'laws', that is their necessary relations. This 'framework' required that the text of scripture be examined on the same basis as any other text in the total corpus of ancient literature. 


\subsection{The lost relationship between theology and church}

During the course of the last two centuries theology as a university discipline mostly lost its close relationship with the church. It was practised outside the control of the church and within the orbit of the modern concept of science (Bosch, 1992:10). Its meaning for the life of the congregation became very limited. Theology as an university discipline did not really inspire authoritative preaching of the Word of God, because its ethos was not that of the church, but that of the scientific community. It did not help the preacher to speak with the power of a Verbi Divini Minister. That many preachers were still able to do that was in spite of, and not because of, the kind of theology that they had been taught. This development was extremely harmful to Protestant churches, precisely because of the specific relation between church and theology in the Protestant tradition. Since the 18th century the mainline churches progressively lost the power to inspire the congregation with a vision of the Kingdom of God. The 19th century tells the story of the struggle, the secession, the estrangement resulting from this development in the Reformed Churches (Schrotenboer, 1992). The influence of the church on its environment often became minimal, because it could not reflect any clear, let alone inspiring Christian identity. Many churches became bourgeois institutions supporting the civil religion of the political society. Reformed churches, like many others, suffered from complacency and uncertainty. This was caused presumably by an academic theology that could not really inspire the life of the congregation. We are reminded of Van 't Spijker's statement that in the long run the character of the church is determined by its theology.

It is often said that the type of answers given by the Reformation in the 16 th century simply do not fit the kind of questions asked by people in the 20th century. This statement also implies that the kind of answers that the Bible gives are no longer relevant for the present situation. Since the sixties, numerous new types of modernist theologies have succeeded one another, some more provocative than others. Common to them all was the fact that they were short-lived and soon forgotten. Their existence was symptomatic of the theological void into which the Christian community world-wide had been plunged. 


\subsection{The threatened identity of the church}

In countries all over the world many churches find themselves in the predicament of having lost their confessional and theological identity. This is also true of the Reformed family of churches. It would be easy to cite examples of this situation from all countries. Alan Sell (1992) describes a typical situation when he writes about the doctrinal diversity among Reformed Christians and churches in America. It is well known that Reformed or Presbyterian theology has had a great impact in America, especially because of the influence of theologians and theological institutions of a very high standing (Wells, 1985; Bratt, 1984). Yet, according to Sell, modern developments have threatened the identity of these churches. He is especially disturbed by the negative attitude in many of these churches towards the classical Reformed confessions. He is not even sure if any consensus could be found on the matter of what it really means to be Reformed. Not only does it seem as if anything is acceptable within the tolerant climate of the churches, but the most typical persuasions of the Reformed tradition often seem the least acceptable (Sell, 1992:433ff). In the same vain, Boice (1985:307) complains about the pervasive Arminian slant in Protestant America, even in churches of Reformed origin. The same type of complaint could be heard about Reformed churches around the world.

While one cannot say that those churches which have been influenced by modernism have totally lost their Christian identity, it is nevertheless clear that their confessional identity is threatened. The deepest reason for this loss of identity must be sought in the lack of certainty that the Scriptures are indeed the Word of God, the lamp to our feet and the light for our path (Ps. 119:105). The modern spirit has undermined the 'plausibility structures' within which an appeal to the Scriptures could be meaningful. As a result of this undermining an atmosphere of uncertainty has been created which has a significant effect on the preaching, teaching and pastoral care of the church. Many pastors have lost their confidence in the traditional message of the church. Some try to make their preaching relevant by talking about morals or politics. Others try to revitalise the church services by borrowing liturgical elements from other ecclesiastical traditions or by introducing the style and spirituality of the Charismatic Movement. Quite often the pastoral ministry of the church is replaced by 
psychotherapy or by the stimulation of a kind of mystical meditation borrowed from the East. When the pastor has lost his trust in the proclamation of the saving and healing Word of God, he has to look for something else to replace it.

\section{The challenge of the present situation}

We are confronted by the challenge of finding a way back to the kind of theology that could serve the identity of the congregation in our present situation. The modernist quest for relevancy has brought many churches to the brink of theological bankruptcy. A mere return to the historical position of the Orthodoxy is hardly possible. If they want to fulfil their calling in the present situation, church and theology will have to revitalise the basic powers that were at work in the Reformation. Only then will they once again be able to protect and to strengthen the integrity of Reformed theology and the identity of the Christian congregation.

\subsection{Resisting the modernistic trend}

In this regard, we should take heed of the lessons that have been learnt since the 18 th century. We must also be thankful that the faith of the Church has survived the cultural onslaught. This survival was due largely to the existence of Christians, churches and groups who had the courage to resist the general modernistic trend and to remain faithful to the Biblical truth as expressed in the classical creeds of the Church. God in his mercy, kept alive the faith in the gospel. We need therefore to be thankful to him for the many theologians who did not accept all the consequences of the modern presuppositions, despite the pressure exerted on them to do so by the theological faculties in which they served and which operated on these modem principles. We cannot ignore the work and testimony of many theologians who struggled to find some place to stand within the new intellectual climate, even though we may be critical of the way in which they chose to do it.

The challenge Reformed theology has today is to confront the reality of the secularised world in such a way that the Word of God will be heard, even by people who seem to have no frame of reference other than that presented by the secular age. We will have to trust the Spirit of God to guide us and to bless our testimony in a world in which we are confronted 
with the phenomenon of massive unbelief and a disregard for the Bible and the church. The congregation itself is the appropriate starting point. The congregation should be helped to attain a clear vision of its own identity and be encouraged to live unashamedly as Christians. It must learn to trust in the power of God who, even in this post-Christian era with its unbelief and syncretism, is strong enough to overcome the obstacles in the way of faith.

\subsection{The limitations of the Enlightenment}

From the basis of the Christian faith we are able to make a proper assessment of the real meaning of the cultural shift that took place in the Enlightenment. Nobody should deny the positive side of the Enlightenment in our cultural history. The Enlightenment freed us from a lot of superstition and opened the door to the enormous scientific developments in the Western world. But at the same time it was dangerous because of its one-sidedness; its over-simplification of reality; its belief that scientific knowledge could encompass the whole truth; its 'Promethean optimism' (Hall, 1991:37); and its conviction that faith in a special revelation of God was childish in nature and therefore unacceptable to the modern mind. At the end of the traumatic twentieth century, we are in a better position to understand the shortsightedness, one-sidedness and therefore also the relative character of the Enlightenment and its presuppositions. The modern mind should be seen for what it really was: a biased and positivistic approach to reality that could in no way honour its fullness. It was not necessarily modern science per se that led to the unbelief that characterises the modern era (Torrance, 1982). There were also specific cultural factors in the Western intellectual development that led to this choice. Today there is a new realisation that the modern era, with its specific type of approach, is drawing to an end. The post-modern era, into which we have entered already, allows a more pluralistic approach to reality and new possiblities for theology (Brueggemann, 1993:1-8).

Since the time of Schleiermacher, theological modernism tried to reconcile theology and modern culture. The Biblical message was reduced to what could be fitted into the plausibility structures of the modern culture. Because of the limitations given with the presuppositions of the Enlightenment, this reduction led to a distortion of the message of the 
Bible. As long as the presuppositions of the Enlightenment are taken as valid, they will obstruct the way to the acceptance of the authority of the Bible. Once the one-sidedness and relative character of these presuppositions are exposed, the way is opened to listen to the Biblical message with new ears.

The question is of course, how people should be convinced of the deficiency of their presuppositions. The theological apologetics of the last two centuries has tried to do this in many ways, but with little success. The reason for this failure is that presuppositions cannot easily be changed on the intellectual level alone. More especially, those presuppositions that obstruct the decision of faith cannot be removed by logical argument. This is the valid point in Karl Barth's rejection of Christian apologetics (Barth, 1947:25ff). This kind of obstruction can only be removed by the persuasion of the Spirit of God within the community of faith. That is why it is so important to have a living faith community in which the authority of the Bible is accepted. Such a community may be instrumental in helping the people of our day to read and understand the Bible as the Word of God in a new way.

\subsection{The congregation as interpretative community}

At present there is a growing awareness of the interpretative role of the community in our understanding of reality and the reading of the Bible (McKnight, 1988:167ff; Watson, 1993:4). We never read the Bible on our own or in a disinterested way. As a rule, people read the Bible as members of an interpretative community with specific "interpretative interests" in its reading (Fowl \& Jones, 1991:15). This is true of the congregation. It is also true of academics and of those who read the Bible with a view to its relevancy for life in society (cf. the political theology of all ages). It is always relevant to ask why people read and interpret the Bible if one really wants to understand the way in which they go about it. The 'context' within which the Bible is read, always plays a role in its appropriation.

The concept of contextualisation refers to the way in which the message of the gospel is received and appropriated in a missionary situation. The world of the listener plays a very definite role in the reception of the gospel (Luzbetak, 1989; Conn, 1984). For the Bible to be understood 
and internalised, its message has to be interpreted and lived anew in each human culture (Bosch, 1991:452). Although the truth of God is supracultural, and can be communicated to many different cultures, it cannot be communicated to all cultures in the same way. It cannot be communicated supra-culturally (Carson, 1987:249-253). It needs to be 'contextualised' in each culture: it needs to be seen in its relevancy for its readers within their own context.

In an analogous way, every reader of the Bible comes to it with his or her own world and reads it influenced by his or her own interests. The reader who approaches the Bible with the presuppositions of the modern era and reads it within the context of the modern university, will have a totally different interest in reading the text from that of a reader from the community of faith who is in need of salvation or comfort (McKnight, 1988:73-76). Nobody should think that the first reader, with his or her scientific knowledge, necessarily has a better chance of understanding the message of the Bible than has the ordinary member of the congregation. The congregation needs not feel itself threatened by the fact that the Bible is also read in the university and is then interpreted in an historical-critical way. It should see this approach for what it is: one way to go about reading the Bible. The academic context of the university prides itself in its non-committal stance as far as the convictions of faith are concerned. While such a stance is possible, these academics must also realise that the correct way of reading the Bible is to read it within the context of the church.

\subsection{The Bible as book of the church}

A distinction must be made between the Bible as book of the church, and the Bible as book of the university or the society (Betz, 1981; Tracy, 1981). The church, as Newbigin has pointed out,

$\ldots$ is that community which, in an unbroken succession with Abraham, lives by the faith to which the Bible bears witness, and continues to testify in face of all other claims that it is in this faith that the truth is to be known in its fullness. That is an absolute faith commitment; it cannot be validated by reference to something else presumed to be more reliable ... The Bible can never be, for the Church, a collection of texts from the past which can be studied 'objectively' by a scholar who remains uncommitted to their truth ... 
The only proper 'interest' of the Church in the study of scripture is the glory of the one who speaks to the Church in scripture (Newbigin, 1985:46).

Any attempt to read the Bible in a neutral way, merely as an historical document, is to read it without a true understanding of its intentions. The church has always believed that the Holy Spirit alone can open our eyes to understand the Bible properly. The congregation is the community in which the Spirit works and lives. Therefore it is the proper locus for the interpretation of the Bible (Hall, 1991:289f; Wentsel, 1982:146). It is always a bad sign when theology ignores the contribution of the congregation in its attempt to understand the Bible (Van 't Spijker, 1974: 40). According to Rossouw, Calvin subscribed to the idea that the interpretation of the Bible as the Word of God can never be a private matter. Rather, the church, as the historical community of present and past believers, forms the hermeneutical continuum in which the interpretation of Scripture should be carried out (Rossouw, 1982:179180). Fowl and Jones (1991) argue that people can only become 'wise readers' of the Bible if they form part of a living community of disciples and have acquired the formation and transformation of character appropriate to disciples of Jesus. True understanding of the Scripture is part of the kind of life within the fellowship of believers. Similar positions, although from different angles and with different accents, are taken in by Bird (1982), Jodock (1989), Schneider (1991) and Hall (1991).

Reading the Bible as the book of the church means that it is read with specific presuppositions. It is read as a unity, not just as a collection of different documents. It is also read from a specific perspective and in a specific interpretational framework, supplied by the long history of the church's reading and interpretation of it (Smit, 1991:167-168; Runia, 1988:94-95). To read it like that, is to read the Bible as Scripture and as the Word of God (Kelsey, 1975:198ff; Van Ruler, 1968:113). It is to interpret it according to the analogia fidei, the analogy of faith (Greijdanus, 1946:14-143; Runia, 1972:18). This way of reading the Bible may be unacceptable to the modernist academic scholarship with its aim of a detached and critical reading of the text. According to this approach, the way in which the church reads the Bible is dogmatic and biased. Ironically, Biblical scholarship, as it is conducted in the modernist 
tradition, is itself not neutral at all. The 'neutrality' of critical scholars is already a decision against the faith which the text intends to evoke (Newbigin, 1985:44).

Apart from that, the scholarly community often brings its own interests and interpretational framework to its reading of the Bible. Just as the interpretation of the text by the preacher is not disinterested because he/she intends to persuade the congregation of the truth of the Biblical message, also the interpretation of the scholar is not disinterested. Scholars are part of an institution which measures success in terms which are set by the existing culture. They themselves have a clear interest in achieving success in these terms (Newbigin, 1985:45). Their work is often of little use to the community of faith which should have been served by theology in the first place. Biblical scholars should be challenged not just to read the Biblical writings separately and within the confines of their academic world, but to read them also (or even in the first place) as a collection, as the book of the church and as canon, in order to serve the community of faith (Smit, 1992:303-325).

We must face the challenge to proclaim anew the message of the Word of God. We must do this in such a way that it will provide the people of our time with a frame of reference and a new set of presuppositions that will enable them to see the relevance of the Bible for their own life and for that of the world. Within a situation of great confusion in the spiritual orientation of the world, the church should rejoice in the reality of God's revelation, the reality of the Scriptures as the Word of God, and the reality of reconciliation in Christ. These three pillars form the foundation of the church (Van 't Spijker, 1974:40-49). Theology should help the church to fulfil its calling in this turbulent time, and not add to the existing spiritual disarray. In order to be able to do this, theology should get clarity about its relation to the Holy Scriptures.

\subsection{The congregation and the identity of theology}

Strangely enough, we have arrived at a very interesting point in the discussion about the relation between theology and congregation. We started off by referring to the role that Reformed theology played, and still has to play, in the building up of the congregation and in the protection of its identity. But now it seems that in modern times the congregation may 
have the task of reminding theology of its own identity, an identity that has been threatened during the last two centuries. The congregation will have to remind theology of its proper nature as the scientific attempt to read, to understand and to interpret the message of the Bible in such a way that the church will be built up in faith and will be enabled to fulfil its proper task in the world. Essentially, theology is nothing else than the self-reflection of the faith community (Hall, 1991:58). It can best be done from within a community where faith is the source of knowledge (Bosch, 1992:14). This does not mean that theology should be practised in a spirit of dogmatic exclusivism that does not take heed of the world at large, but it does mean that theology should take the Bible seriously as the Word of God (Carson, 1987:253; Van 't Spijker, 1974:40-49).

In the preface to his book on The Reformed Imperative (1988), John Leith writes that many factors have no doubt contributed to the declining role of the Presbyterian and other mainline churches in American life. He then adds:

This book is written, however, in the conviction that the primary source of the decline is to be found in the loss of the theological integrity and competence of the church's witness, in particular in preaching, teaching and pastoral care ... The renewal of the church will not come without the recovery of the authenticity and theological integrity of the church's message and a renewed emphasis on preaching (Leith, 1988:13).

This rediscovery is only possible if the Bible as the book of the church is taken seriously both by theologians and by the congregation. Reformed theology can fulfil its calling only if it stays in close relation with the congregation whose identity it is called upon to protect and serve. We cannot avoid making a clear choice between a type of theology that takes revelation seriously and a type of theology that does not. If Reformed theology is to retain its vitality, it will have to take its place within the living faith of the congregation of Christ.

\section{Bibliography}

BAKKER, J.T. 1957. Kerugma en prediking. Kampen : Kok.

BALKE, W. 1992. Omgang met de Reformatoren. Kampen : De Groot Goudriaan.

BARTH, K. 1958. Fides quaerens intellectum. Anselms Beweis der Existenz Gottes. Dritte Auflage. Zürich : Evangelischer Verlag. 
BARTH, K. 1947. Die Lehre vom Wort Gottes. Kirchliche Dogmatik I/1. Zollikon-Zürich : EVZ.

BERKHOF, H. 1985. 200 Jahre Theologie. Ein Reisebericht. NeukirchenVluyn : Neukirchener Verlag.

BETZ, H.D. ed. 1981. The Bible as Document of the University. Chico : Scholars Press.

BIRD, P.A. 1982. The Bible as the Church's Book. Philadelphia : Westminster Press.

BOICE, J.M. 1985. The Future of Reformed Theology. (In Wells, D.F. ed. Reformed Theology in America. Grand Rapids : Eerdmans. p. 299-311.)

BOSCH, D.J. 1991. Transforming Missions. Paradigm Shifts in Theology of Mission. Maryknoll, New York : Orbis Books.

BOSCH, D.J. 1992. Theological Education. Theologia Evangelica, 25(1):823, March.

BOUWSMA, W.J. 1988. John Calvin. A Sixteenth Century Portrait. Oxford : OUP.

BRATT, J.D. 1984. Dutch Calvinism in Modern America. Grand Rapids : Eerdmans.

BRUEGGEMANN, W. 1993. The Bible and Postmodern Imagination. London : SCM.

CARROLL, J.W. 1991. Preserving Christian Identity. (In Dudley, C.S., Carroll, J.W. \& Wind, J.P. eds. Carriers of Faith. Lessons from Congregational Studies. Louisville : John Knox Press. p. 25-140.)

CARSON, D.A. 1987. Church and Mission: Reflections on Contextualization and the Third Horizon. (In Carson, D.A. ed. The Church in the Bible and the World. Grand Rapids : Baker. p. 213-257.)

CONN, H.M.C. 1984. Eternal Word and Changing Worlds. Grand Rapids : Zondervan.

DE MOOR, J.C. 1980. Towards a Biblically Theological Method. Kampen : Kok.

FOWL, S.E. \& JONES, L.G. 1991. Reading in Communion. London : SPCK. GASSMANN, B. 1968. Ecclesia Reformata. Die Kirche in den reformienten Bekenntnisschriften. Freiburg : Herder.

GRAAFLAND, C. 1990. Gereformeerden op zoek naar God. Godsverduistering in het licht van de gereformeerde spiritualiteit. Kampen : De Groot-Goudriaan.

GRANT, R.M. \& TRACY, D. 1984. A Short History of the Interpretation of the Bible. 2nd ed. Philadelphia : Fortress.

GREIJDANUS, S. 1946. Schriftbeginselen ter Schriftverklaring. Kampen : Kok. 
HALL, J.H. 1991. Thinking the Faith. Christian Theology in a North American Context. Minneapohis : Fortress Press.

HERON, A. 1980. A Century of Protestant Theology. Guilford and London : Lutterworth Press.

HOPEWELL, J.F. 1987. Congregation. Stories and Structures. Philadelphia : Fortress Press.

HOUGH, J.C. \& COBB, J.B. 1985. Christian Identity and Theological Education. Chico, California : Scholars Press.

JACOBS, P. 1959. Theologie reformierter Bekenntnisschriften in Grundzïgen. Neukirchen : Neukirchener Verlag.

JODOCK, D. 1989. The Church's Bible. Its Contemporary Authority. Minneapolis : Fortress Press.

JONKER, W.D. 1987. Die kerklik-teologiese implikasies van die Kairosdokument. (In Hofmeyr, J.W., Du Toit, J.H.H. \& Fronemann, C.J.J. reds. Perspektiewe op Kairos. Kaapstad : Lux Verbi. p. 74-88.)

JONKER, W.D. 1989. Die eie-aard van die gereformeerde spiritualiteit. Ned Geref Teol Tydskrif, 30(3):288-299, Jul.

KELSEY, D.H. 1975. The Uses of Scripture in Recent Theology. Philadelphia : Fortress Press.

KLAPPERT, B. 1976. Promissio und Bund. Gesetz und Evangelium bei Luther und Barth. Göttingen : Vandenhoeck and Ruprecht.

KUYLMAN-HOEKENDIJK, L. 1969. Dwarslagen in de Christenheid. Baarn : Bosch \& Keuning.

KUYPER, A. 1930. Souvereiniteit in eigen kring. Kampen : Kok.

LEITH, J.H. 1988. The Reformed Imperative. Philadelphia : Westminster Press.

LINDBECK, G. 1984. The Nature of Doctrine: Religion and Theology in a Post-Liberal Age. Philadelphia : Westminster.

LUZBETAK, L.J. 1989. The Church and Cultures. Marknoll, New York : Orbis Books.

MARXSEN, W. 1968. Der Exeget als Theologe. Gütersloh : Gütersloher Verlagshaus Gerd Mohn.

McKNIGHT, E. 1988. Post-Modern Use of the Bible. Nashville : Abingdon.

NEWBIGIN, L. 1985. The Other Side of 1984. Questions for the Churches. Geneva : World Council of Churches.

NIESEL, W. 1960. Das Evangelium und die Kirchen. Neukirchen : Neukirchener Verlag.

PANNENBERG, W. 1973. Wissenschaftstheorie und Theologie. Frankfurt a M. : Suhrkamp Verlag. 
ROSSOUW, H.W. 1963. Klaarheid en interpretasie. Enkele probleemhistoriese gesigspunte in verband met die leer van die duidelikheid van die Heilige Skrif. Amsterdam : Jacob van Campen.

ROSSOUW, H.W. 1982. Calvin's Hermeneutics of Holy Scripture. (In

Calvinus Reformator. Potchefstroom. PU vir CHO. p. 149-180.)

RUNIA, K. 1972. Prediking en historisch-kritisch onderzoek. Kampen : Kok.

RUNIA, K. 1988. Waar blijft de kerk? Kampen : Kok.

SCHOLDER, K. 1966. Ursprünge und Probleme der Bibelkritik in 17. Jahrhundert. München : Kaiser Verlag.

SCHNEIDER, S.M. 1991. The Revelatory Text. Interpreting the New Testament as Sacred Text. San Francisco : Harper \& Collins.

SCHROTENBOER, P.G. ed. 1992. Catholicity and Secession. A Dilemma? Kampen : Kok.

SELL, A.F.P. 1992. The Reformed Family Today: Some Theological Reflections. (In McKim, Donald K. ed. Major Themes in the Reformed Tradition. Grand Rapids : Eerdmans. p. 433-441.)

SMIT, D.J. 1991. Wat beteken 'die Bybel sê'? 'n Tipologie van leserskonstrukte. Hervormde Teologiese Studies: 167-185, Maart.

SMIT, D.J. 1992. 'Oor Nuwe-Testamentiese Etiek'. Die Christelike lewe in Suid-Afrika vandag. Scriptura. Journal of Bible and Theology in South Africa. Spesiale uitgawe:303-325.

TORRANCE, T.F. 1982. Das Verhältnis zwischen christlichem Glauben und moderner Naturwissenschaft. IBW Journal. Sonderbeilage zu Heft 2, Februar.

TRACY, D. 1981. The Analogical Imagination. Christian Theology and the Culture of Pluralism. London : SCM.

VAN GENDEREN, J. \& VELEMA, W.H. 1992. Beknopte gereformeerde dogmatiek. Kampen : Kok.

VAN RULER, A.A. 1955. Die christliche Kirche und das Alte Testament. München : Kaiser Verlag.

VAN RULER, A.A. 1968. Schrift en gezag. (In Berkouwer, G.C. \& Van der Woude, A.S. red. De Bijbel in het geding. Nijkerk : Callenbach. p. 113128.)

VAN 'T SPIJKER, W. 1974. Eenheid in verscheidenheid? De identiteitscrisis binnen de Gereformeerde Gezindte. Kampen : Kok.

VAN 'T SPIJKER, W., BALKE W., EXALTO, K. \& VAN DRIEL, L. reds. 1993. Spiritualiteit. Kampen : De Groot Goudriaan.

VELEMA, W.H. 1990. Nieuw zicht op gereformeerde spiritualiteit. Kampen : Kok Voorhoeve.

WATSON, F. ed. 1993. The Open Text. New Directions for Biblical Studies. London : SCM. 
WELLS, D.F. ed. 1985. Reformed Theology in America. Grand Rapids : Eerdmans.

WENDEL, F. 1976. Calvin. The Origins and Development of His Religious Thought. Fontana Library. London/New York : Collins

WENTSEL, B. 1982. De openbaring, het verbond en de apriori's. Dogmatiek II. Kampen : Kok. 
